University of Nebraska - Lincoln

DigitalCommons@University of Nebraska - Lincoln

Papers in the Earth and Atmospheric Sciences

Earth and Atmospheric Sciences, Department

July 2005

\title{
Holocene hydrologic variation at Lake Titicaca, Bolivia/Peru, and its relationship to North Atlantic climate variation
}

\author{
P. A. Baker \\ Duke University, pbaker@duke.edu \\ Sherilyn C. Fritz \\ University of Nebraska-Lincoln, sfritz2@unl.edu \\ J. Garland \\ Duke University \\ E. Ekdahl \\ University of Nebraska-Lincoln
}

Follow this and additional works at: https://digitalcommons.unl.edu/geosciencefacpub

Part of the Earth Sciences Commons

Baker, P. A.; Fritz, Sherilyn C.; Garland, J.; and Ekdahl, E., "Holocene hydrologic variation at Lake Titicaca, Bolivia/Peru, and its relationship to North Atlantic climate variation" (2005). Papers in the Earth and Atmospheric Sciences. 37.

https://digitalcommons.unl.edu/geosciencefacpub/37

This Article is brought to you for free and open access by the Earth and Atmospheric Sciences, Department of at DigitalCommons@University of Nebraska - Lincoln. It has been accepted for inclusion in Papers in the Earth and Atmospheric Sciences by an authorized administrator of DigitalCommons@University of Nebraska - Lincoln. 


\title{
Holocene hydrologic variation at Lake Titicaca, Bolivia/Peru, and its relationship to North Atlantic climate variation
}

\author{
P. A. Baker, ${ }^{1 *}$ S. C. Fritz, ${ }^{2,3}$ J. Garland, ${ }^{1}$ and E. Ekdahl ${ }^{2}$ \\ ${ }^{1}$ Division of Earth and Ocean Sciences, Nicholas School of the Environment and Earth Sciences, Duke University, Durham, NC, \\ USA \\ ${ }^{2}$ Department of Geosciences, University of Nebraska-Lincoln, Lincoln, NE, USA \\ ${ }^{3}$ School of Biological Sciences, University of Nebraska-Lincoln, Lincoln, NE, USA \\ * Corresponding author - P. A. Baker, Division of Earth and Ocean Sciences, Nicholas School of the Environment and Earth \\ Sciences, Duke University, Durham, NC 27708-0227, USA. Email pbaker@duke.edu
}

\begin{abstract}
A growing number of sites in the Northern Hemisphere show centennial- to millennial-scale climate variation that has been correlated with change in solar variability or with change in North Atlantic circulation. However, it is unclear how (or whether) these oscillations in the climate system are manifest in the Southern Hemisphere because of a lack of sites with suitably high sampling resolution. In this paper, we reconstruct the lake-level history of Lake Titicaca, using the carbon isotopic content of sedimentary organic matter, to evaluate centennial-to millennial-scale precipitation variation and its phasing relative to sites in the Northern Hemisphere. The pattern and timing of lake-level change in Lake Titicaca is similar to the ice-rafted debris record of Holocene Bond events, demonstrating a possible coupling between precipitation variation on the Altiplano and North Atlantic sea-surface temperatures (SSTs). The cold periods of the Holocene Bond events correspond with periods of increased precipitation on the Altiplano. Holocene precipitation variability on the Altiplano is anti-phased with respect to precipitation in the Northern Hemisphere monsoon region. More generally, the tropical Andes underwent large changes in precipitation on centennial-to-millennial timescales during the Holocene.
\end{abstract}

Keywords: palaeoclimate, South America, tropics, Altiplano, Bond events.

\section{Introduction}

Recent studies from many sites in the Northern Hemisphere show centennial-to millennial-scale climate variation that has been correlated directly with changes in atmospheric radiocarbon production or with changes in North Atlantic oceanic circulation that also may be linked to atmospheric radiocarbon production and presumed solar variability (e.g. Bond et al., 1997, 2001; Hodell et al., 2001; Neff et al., 2001; Fleitmann et al., 2003; Hu et al., 2003; Rohling and Pälike, 2005; Wang et al., 2005). However, despite a growing body of palaeoclimatic data from the Southern Hemisphere tropics of South America, patterns of hydrologic variation at these timescales are not as well known, because of the lack of records at suitably high resolution that span the entire Holocene. Thus, it is unclear how centennial-to-millennial variability in the climate system is manifest in the region, and how (or whether) these changes are correlated with climatic events in the Northern Hemisphere. In this paper we will address two questions: is there evidence in the
Holocene record of Lake Titicaca for climatic changes that correlate with "Bond events" (Bond et al., 1997) of the North Atlantic and, if so, what is the phasing of these Altiplano events with respect to records from the North Atlantic and the Indian/Asian monsoon regions?

\section{Site description}

Lake Titicaca $\left(16^{\circ} \mathrm{S}, 69^{\circ} \mathrm{W}\right)$ lies at $3810 \mathrm{~m}$ on the Altiplano of Boliva and Peru (Fig. 1), a high-elevation internally drained plateau. The lake consists of a large $\left(7131 \mathrm{~km}^{2}\right.$ ) deep (maximum depth $284 \mathrm{~m}$; mean depth $125 \mathrm{~m}$ ) main basin and a smaller $\left(1428 \mathrm{~km}^{2}\right)$ shallow basin (maximum depth $42 \mathrm{~m}$; mean depth $9 \mathrm{~m}$ ), connected at the Straits of Tiquina (25 m depth). Hydrologic inputs to the contemporary lake are balanced between direct rainfall (47\%) and inflow from six major rivers (53\%). Modern water export is primarily via evaporation (91\%), with $<9 \%$ loss via the sole surface outlet, the Rio Desaguadero at $3804 \mathrm{~m}$ elevation (Roche et al., 1992). Twentieth-century lake-level as 


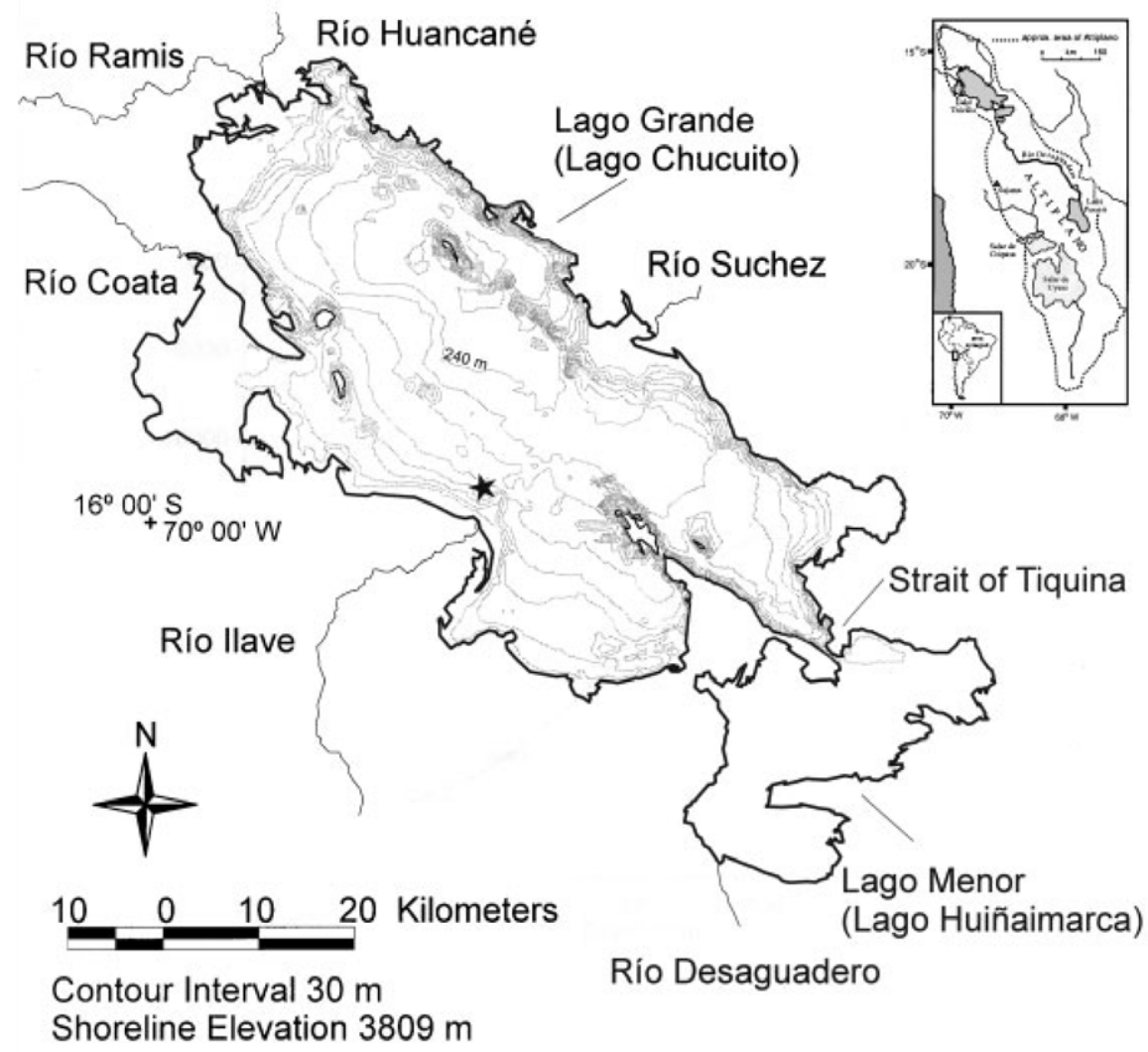

Figure 1 Map of Lake Titicaca showing the location of the NE98-PC2 core (indicated by the star).

measured at Puno has varied by ca. $6.5 \mathrm{~m}$ (SENAMHI, Peru) and is influenced primarily by wet season precipitation on the lake (rather than evaporative loss (Rigsby et al., 2003)). The lake is oligosaline $\left(0.1 \mathrm{~g} \mathrm{~L}^{-1}\right.$ salinity) and moderately productive (mesotrophic).

\section{Methods}

\section{Field}

Piston cores were obtained from multiple locations in Lake Titicaca in 1998. This paper focuses on high-resolution analyses from NE98-PC2 (15 57.4800' S, 69 26.6520' W) obtained in $142 \mathrm{~m}$ water depth in the main basin of the lake, near the Rio Ilave delta (Fig. 1). Total core length was $7.87 \mathrm{~m}$; here we focus on the uppermost $5.7 \mathrm{~m}$ of the record, which spans the last ca. 13,000 years. Magnetic susceptibility was measured in the field. The cores were shipped to the US and stored at $4{ }^{\circ} \mathrm{C}$ prior to sampling.

\section{Chronology}

Core chronology is based on 10 accelerator mass spectrometry ${ }^{14} \mathrm{C}$ dates (Table 1) calibrated using CALIB 4.4 (Stuiver and Reimer, 2004). An age model was generated by fitting a cubic spline through the calibrated dates (Fig. 2). One sample with an age reversal was excluded from the age model. No reservoir correction was applied: unlike the 250-yr reservoir effect found in the shallow southern sub-basin of Lake Titicaca (Abbott et al., 1997), box cores from the much larger and deeper northern sub-basin that recovered the sediment-water interface have been demonstrated to contain bomb radiocarbon (Rowe et al.,

Table 1 Radiocarbon and calibrated ages determined by accelerator mass spectrometry (AMS) on the total organic carbon of the mud

\begin{tabular}{|c|c|c|c|c|c|c|c|}
\hline $\begin{array}{l}\text { Sample } \\
\text { number }\end{array}$ & $\begin{array}{c}\text { Sample } \\
\text { depth }(\mathrm{cm})\end{array}$ & $\begin{array}{l}\delta^{13} \mathrm{C} \\
\mathrm{PDB}\end{array}$ & $\begin{array}{c}\text { Age } \\
\left({ }^{14} \mathrm{C} \text { yr BP }\right)\end{array}$ & $\begin{array}{l}\text { Age } \\
\text { error }\end{array}$ & $\begin{array}{c}\text { Calibrated age } \\
\text { (cal. yr BP) }\end{array}$ & $\begin{array}{c}\text { Upper } \\
\text { (cal. yr BP) }\end{array}$ & $\begin{array}{c}\text { Lower } \\
\text { (cal. yr BP) }\end{array}$ \\
\hline INSTAAR & 20 & 22.1 & 1,070 & 50 & 933 & 799 & 1,056 \\
\hline OS-33544 & 76 & 23.72 & 1,340 & 30 & 1,235 & 1,174 & 1,288 \\
\hline OS-33543 & 142 & 22.84 & 1,970 & 30 & 1,875 & 1,744 & 1,950 \\
\hline OS-41669 & 202 & 22.02 & 2,690 & 40 & 2,769 & 2,730 & 2,850 \\
\hline OS-33542 & 286 & 17.39 & 4,370 & 35 & 4,897 & 4,832 & 5,026 \\
\hline OS-33541 & 324 & 17.6 & 5,560 & 35 & 6,313 & 6,205 & 6,403 \\
\hline INSTAAR & 400 & 17.6 & 7,060 & 65 & 7,837 & 7,691 & 7,955 \\
\hline INSTAAR & 460 & 21.3 & 7,650 & 50 & 8,398 & 8,218 & 8,538 \\
\hline OS-41668 & 516 & 15.78 & 6,970 & 60 & excluded & & \\
\hline OS-33540 & 562 & 23.07 & 10,850 & 60 & 12,878 & 12,634 & 13,108 \\
\hline
\end{tabular}




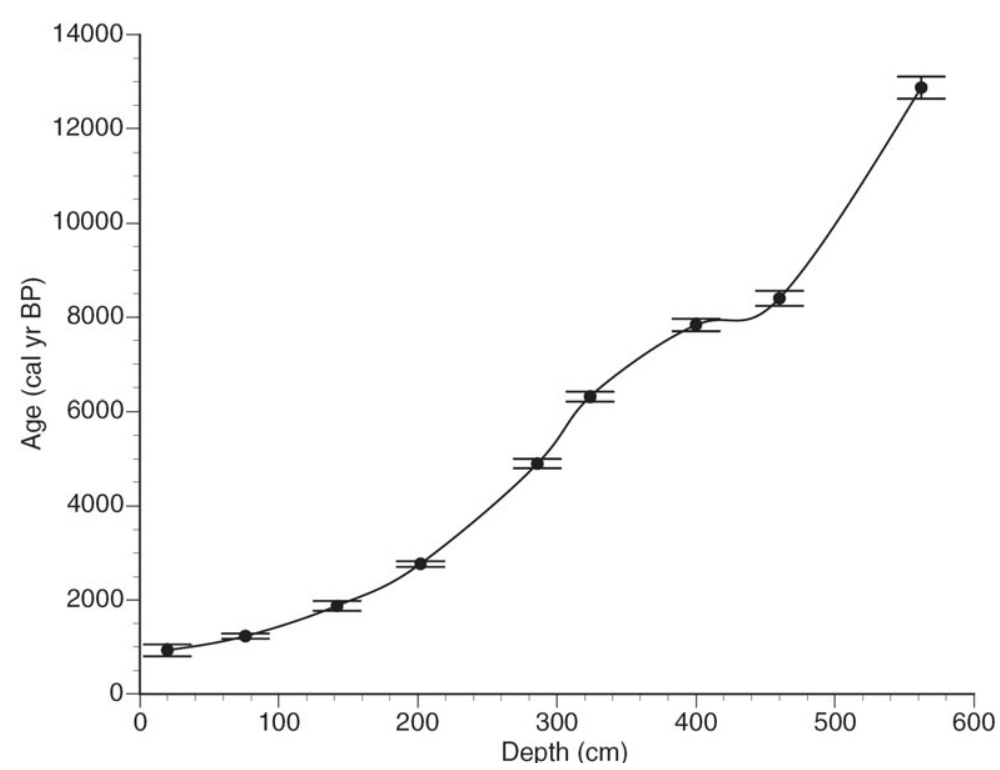

Figure 2 Relationship between core depth and calendar age as established by accelerator mass spectrometry ${ }^{14} \mathrm{C}$ analysis of bulk organic carbon with a cubic spline fit to the dates. Error bars represent $1 \sigma$.

2002) and have no reservoir effect (unpublished data). In almost all cases (including PC-2) piston cores raised from the lake do not recover the sediment-water interface, hence our present record does not extend to age zero.

\section{Geochemistry}

Samples for geochemical analysis were taken at 2-cm intervals throughout the length of the core and subsequently were dried, powdered, weighed and leached in buffered ( $\mathrm{pH}=5.5)$ ammonium acetate-acetic acid. The insoluble residue was rinsed several times in reagent-grade water. Portions of this material were dried and weighed prior to determination of organic carbon and its stable isotopic composition. Organic carbon was determined on an elemental analyzer, and stable carbon isotopic compositions were measured on an isotope ratio mass spectrometer. Carbon isotopic ratios are reported relative to the PDB standard. The precision for the carbon isotopic measurements was $\pm 0.2 \%$.

We reconstruct the lake-level history of Lake Titicaca at decadal to multi-decadal resolution using the $\delta^{13} \mathrm{C}$ of bulk organic matter. This proxy has been previously demonstrated to be a reliable measure of past lake levels during the Holocene in Lake Titicaca (first discussed in Cross et al. (2000), and much more thoroughly documented in Rowe et al. (2002)). Here we briefly review their findings. The flux of terrestrial organic carbon to the deeper portions of Lake Titicaca is generally small, probably a result of two factors-the relatively low vegetative cover of the semi-arid to arid catchment (especially during past periods of greater aridity) and the near-shore trapping of much terrestrial sedimentary input by rooted macrophytes that occur in abundance in the extensive littoral zone of the lake. Hence, the sedimentary organic carbon in Lake Titicaca is largely a mixture of carbon derived from shallow-water rooted macrophytes and planktonic algae. Organic carbon derived from the macrophytes has relatively high values of $\delta^{13} \mathrm{C}$ (and high $\mathrm{C} / \mathrm{N}$ ratios), whereas organic carbon derived from planktonic algae has relatively low values of $\delta^{13} \mathrm{C}$ (and low $\mathrm{C} / \mathrm{N}$ ratios). Modern coretop calibrations of the isotope-depth relationship are very clear: $\delta^{13} \mathrm{C}$ of sedimentary organic carbon decreases with increasing water depth (Rowe et al., 2002, their figure 2c). Further- more, extensive sampling of filtered surface-water samples taken throughout the lake (Rowe, unpublished data) also clearly demonstrates that $\delta^{13} \mathrm{C}$ of particulate organic carbon decreases with increasing distance from the littoral zone of the lake, elucidating the mechanism by which deeper-water sediments obtain their more negative carbon isotopic signature. In the present paper, rather than using $\delta^{13} \mathrm{C}$ of sedimentary organic carbon to quantitatively reconstruct lake level (as done successfully by Rowe et al. (2002)), we hold the proxy to a somewhat lower standard than previously by utilizing variations in $\delta^{13} \mathrm{C}$ simply to assess the timing, but not the magnitude, of lake-level changes.

The rate of change of $\delta^{13} \mathrm{C}$ with depth is much greater between 0 and $100 \mathrm{~m}$ water depth than below $100 \mathrm{~m}$ (Rowe et al., 2002). Thus, during past periods of low lake level (such as the middle Holocene) when the water depth of the sample site decreased from $142 \mathrm{~m}$ to as little as $57 \mathrm{~m}$ (Cross et al., 2000), $\delta^{13} \mathrm{C}$ was a far more sensitive measure of lake-level variation than during highstands. In order to account for the changing variance of $\delta^{13} \mathrm{C}$ that results from long-term secular trends in lake level, we processed the isotopic data as follows. The time series was resampled at evenly spaced $10-y r$ intervals and then smoothed with a 1,000-yr moving window. Subsequently, the data were standardized by subtracting the 1,000-yr running mean from each interpolated value and dividing by the standard deviation over that same interval. This technique retains the original phasing and timing of the centennial-to-millennial scale variability of lake level.

\section{Spectral analysis}

Prior to spectral analysis, the unprocessed $\delta^{13} \mathrm{C}$ time series was resampled and normalized to unit variance. The resampled time series has a resolution of $49.9 \mathrm{yr}$. Long-term trends (greater than ca. 2,500 yr) were removed using singular spectrum analysis (Paillard et al., 1996). The multi-taper method (MTM) of spectral analysis (Mann and Lees, 1996) was used to measure the strength and frequency of periodic signals in the $\delta^{13} \mathrm{C}$ time series. MTM spectral analysis is ideal for red-noise palaeoclimate data, as the technique reduces spectral leakage and allows for calculation of spectral significance using an F-test statistical 
method. Raw spectrum results are plotted against 50\%, 90\%, $95 \%$ and $99 \%$ confidence intervals assuming a red-noise null hypothesis.

\section{Results}

The sediment throughout the core consists of olive-grey to brown mud with faint laminations or banding in sections of the core below $250 \mathrm{~cm}$ (ca. 3,800 cal. yr BP) (Fig. 3). Magnetic susceptibility values are high $(>200)$ in sediments deposited prior to 8,000 cal. yr BP and then decline gradually, reaching values $<20$ SI units after ca. 6,400 cal. yr BP. Calcium carbonate is generally low $(<3 \mathrm{wt} \%)$ throughout most of the sediments dated prior to ca. 5,300 cal. yr BP. Peak values of calcium carbonate occur between 5,300 and 4,000 cal. yr BP (3-30 wt\%), with low values $(<5 \mathrm{wt} \%)$ after 4,000 cal. yr BP.

$\delta^{13} \mathrm{C}$ is relatively depleted prior to $9,000 \mathrm{yr}$ BP $(<24 \%)$, excepting the interval from 10,600 to 10,300 , when values are higher (Fig. 4). Values fluctuate (18 to $25 \%$ ) from 9,000 to 7,600 cal. yr BP, are highest between 7,600 and 4,000 cal. yr BP and subsequently fall to $<20 \%$ after that time.

Spectral analysis of the $\delta^{13} \mathrm{C}$ data (Fig. 5) shows significant periodicities ( $>1: 95 \%$ confidence level) at centennial and multi-centennial scales, including 134, 170, 216-230, 290, 360, 394 and $434-454$ years. Many of these are similar to spectral frequencies associated with solar variability, including the 205$\mathrm{yr}$ deVries frequency and peaks identified in the tree-ring ${ }^{14} \mathrm{C}$ record at 285-300 and 352-357 yr (Stuiver and Braziunas, 1989;

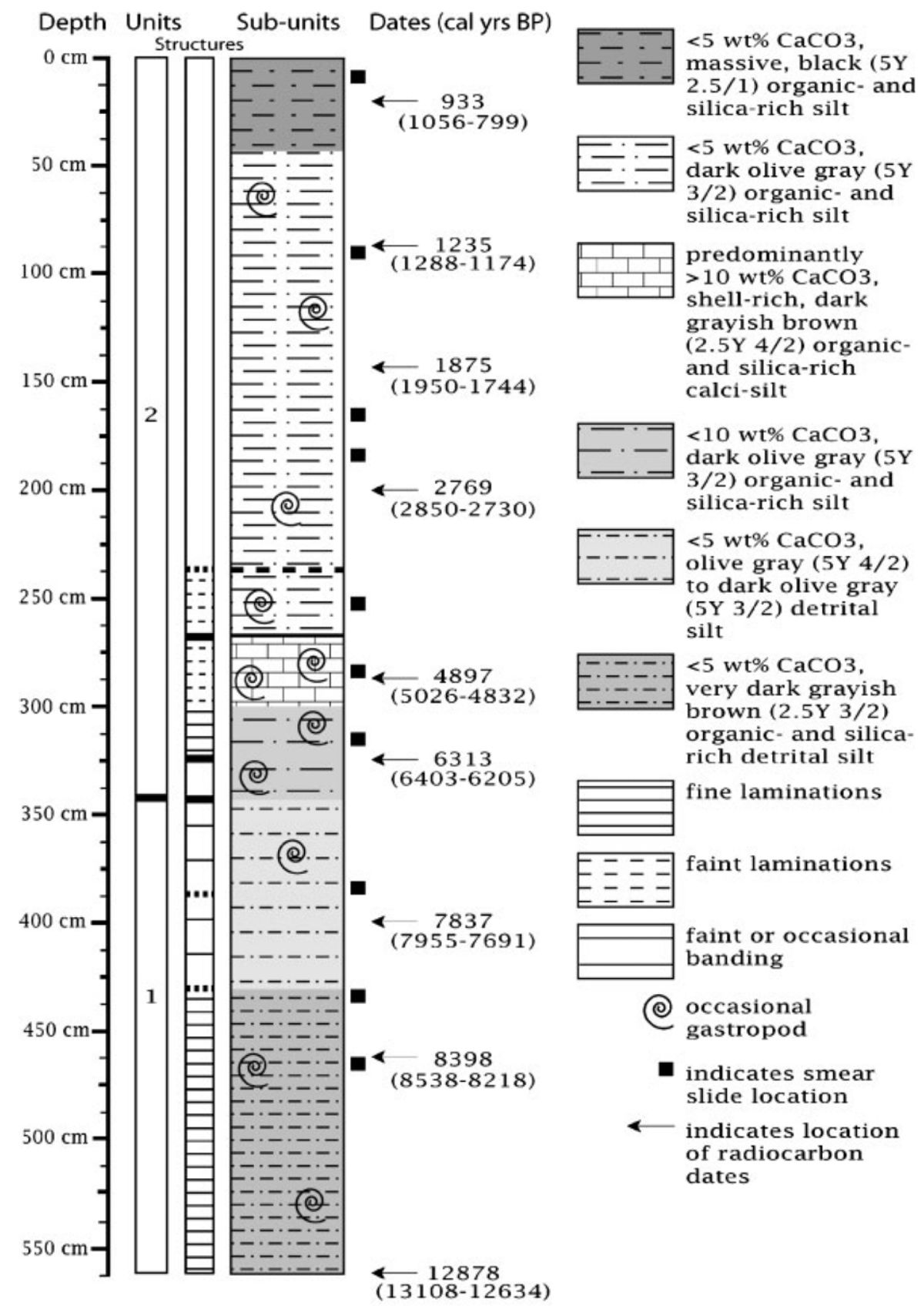

Figure 3 Lithostratigraphy of the NE98-PC2 core showing the general sedimentology and the location of the samples for ${ }^{14} \mathrm{C}$ dating. 


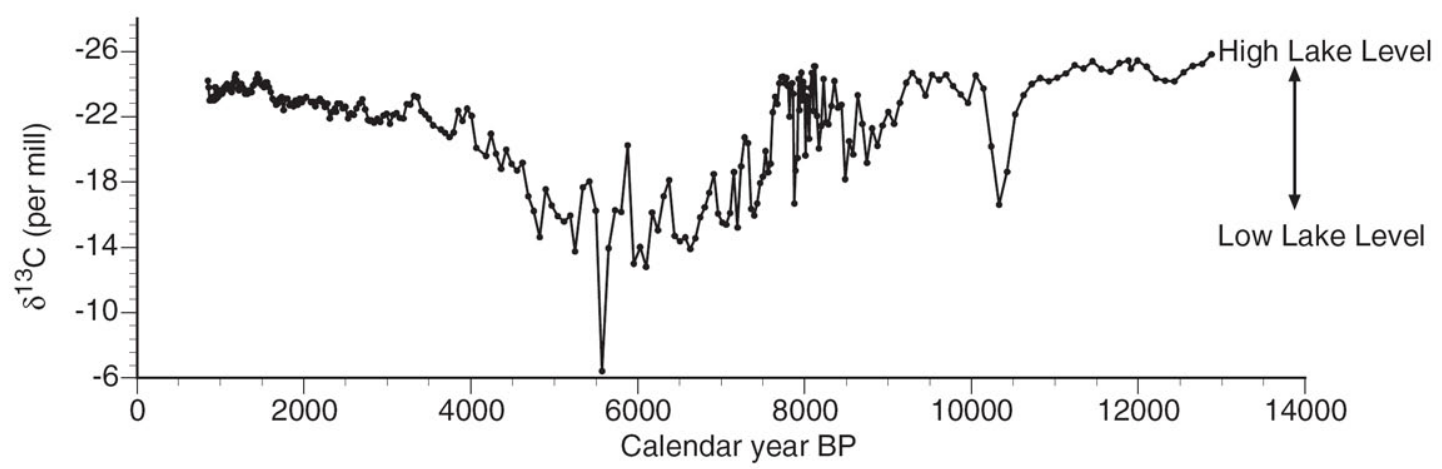

Figure $4 \delta^{13} \mathrm{C}$ of the NE98-PC2 sediments displayed versus calendar age. Depleted (enriched) values of $\delta^{13} \mathrm{C}$ are characteristic of rising or high (low) lake level and thus period of high (low) precipitation.

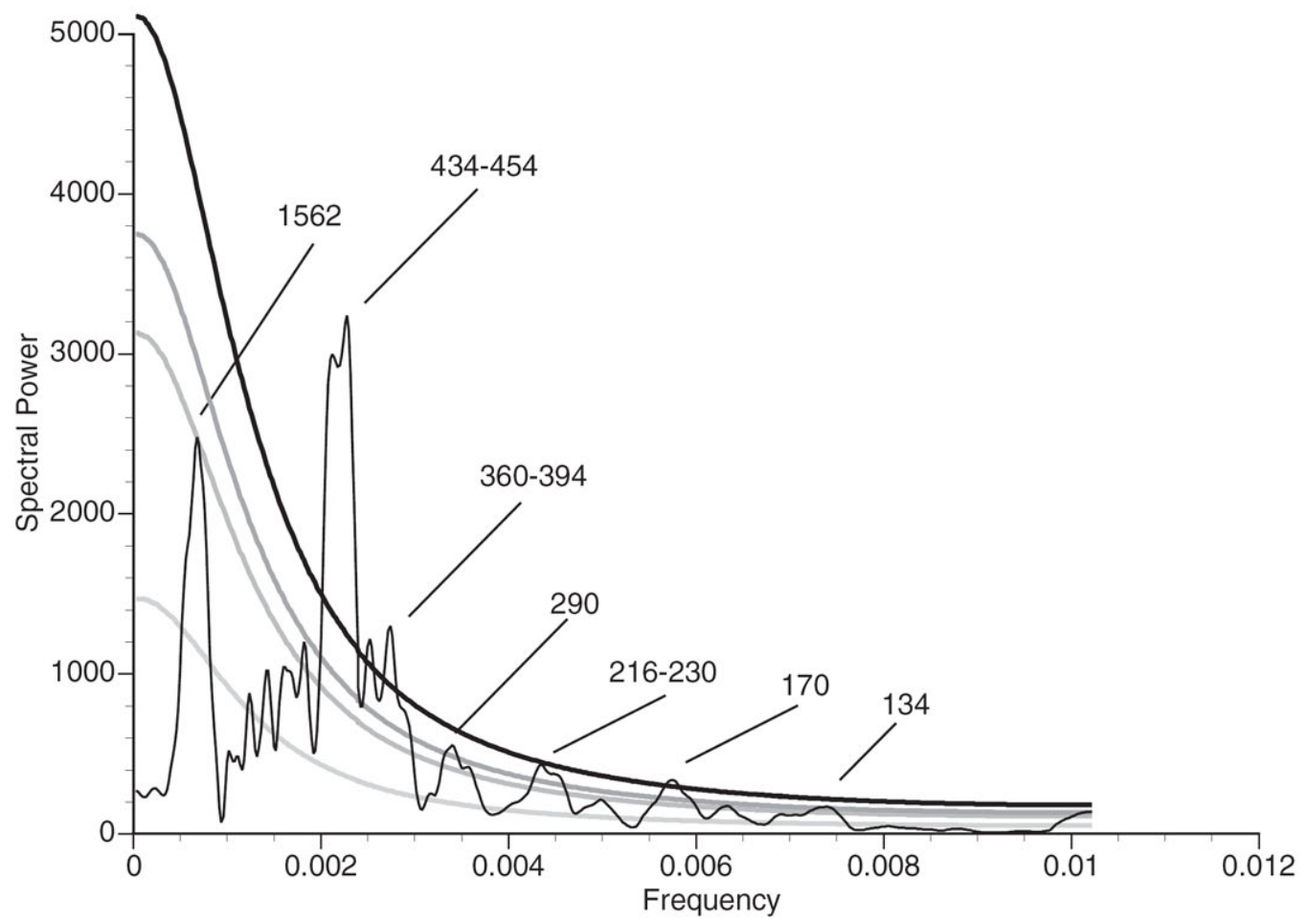

Figure 5 Spectral analysis of the $\delta^{13} \mathrm{C}$ record using the multi-taper method (MTM) (Mann and Lees, 1996). Raw spectrum results are plotted against $50 \%, 90 \%, 95 \%$ and $99 \%$ confidence intervals (from bottom to top) assuming a red-noise null hypothesis

Clemens, 2005). Other significant spectral peaks are at harmonics of the Gleissberg frequency (88 yr). A spectral peak at 1,562 $\mathrm{yr}$, within the quasi-1,500-yr periodicity observed in North Atlantic drift records (Bond et al., 1997), is only weakly significant (90\%).

\section{Discussion}

The overall pattern of change in the carbon isotopic values in NE98-PC2 is similar to that observed in previous studies of Lake Titicaca, partly reflecting the broad-scale influence of the precessional cycle on regional precipitation variation (Baker et al., 2001a, 2001b; Rowe et al., 2002) via its impact on the South American summer monsoon (Zhou and Lau, 1998). Thus, during the early Holocene, isotopic values became increasingly enriched as Lake Titicaca fell to approximately $85 \mathrm{~m}$ below mod- ern level (Seltzer et al., 1998). After 4,000 cal. yr BP, isotopic values become more depleted, as the lake approached the deep, fresh and overflowing conditions of modern times, coincident with the austral summer, Southern Hemisphere insolation maximum. However, the higher resolution analyses for the NE98-PC2 core (mean spacing $40 \mathrm{yr}$; range 8-100 yr) relative to other cores analyzed from the basin allows precipitation variation at centennial-to-millennial timescales to be more clearly defined.

It is well known that interannual precipitation variability in many parts of tropical South America is partly forced by atmospheric circulation patterns associated with equatorial Pacific sea-surface temperature (SST) changes and ENSO (Ropelewski and Halpert, 1987; Aceituno, 1988; Lenters and Cook, 1997; Vuille et al., 2000). An analogous role for the tropical Pacific in forcing past Holocene climate variability of tropical South America, including the Altiplano, has also been supported (e.g. Rodbell et al., 1999; Bradley et al., 2003; Garreaud et al., 2003). In 
this paper we look at an additional role for the Atlantic in forcing part of the Holocene climate variability of the Altiplano.

It is also well known that decadal fluctuations of equatorial Atlantic SSTs are well-correlated with decadal variability of precipitation in the Nordeste region of Brazil (Hastenrath and Heller, 1977; Nobre and Shukla, 1996). There is less observational evidence for the role of the Atlantic in precipitation variability across the Amazon and the Altiplano, although this Atlantic forcing has been supported by several climate and palaeoclimate studies (e.g. Nobre and Shukla, 1996; Melice and Roucou, 1998; Marshall et al., 2001; Baker et al., 2001a, 2001b; Hastenrath et al., 2004; Marengo, 2004; Ambrizzi et al., 2004).

There are many investigations into the mechanisms by which tropical Atlantic variability forces the tropical Atlantic atmosphere (e.g. Chang et al., 1997), but we are unaware of any similar studies that discuss mechanisms that may extend the impact of Atlantic variability as far west as the Altiplano. It seems reasonable that anomalously low SSTs of the equatorial North Atlantic, which are associated with increased easterly lowlevel winds (Nobre and Shukla, 1996; Chang et al., 1997), advect anomalously large quantities of moisture westward into the Amazon, then southeastward toward the South Atlantic Convergence Zone. Perhaps the extra moisture convergence intensifies the South American summer monsoon or perhaps it lengthens the wet season (e.g. Fu and Li, 2004). Further thermodynamic and atmospheric dynamic studies of this problem are warranted.

We have hypothesized previously (Baker et al., 2001a) that SST gradients in the equatorial Atlantic affected precipitation on the Altiplano at decadal timescales and, by analogy, at multicentennial and orbital timescales. We reasoned that if anomalies of near-modern tropical-Atlantic meridional SST gradients, which are generally less than $1{ }^{\circ} \mathrm{C}$ (Chiang et al., 2002), are effective in atmospheric forcing, then much larger equatorial SST gradients at times in the past would have produced much larger atmospheric effects. In a coupled GCM simulation, Vellinga and Wood (2002) found that a large decrease of meridional overturning in the North Atlantic was accompanied by a tripole-like SST cooling pattern of the North Atlantic and attendant warming of the South Atlantic. They observed an anomalous meridional SST gradient across the equatorial Atlantic of approximately $4{ }^{\circ} \mathrm{C}$ (determined in the modern centers of action of the tropical dipole index, see Marshall et al. (2001)). This anomalous SST gradient, in turn, shifted the mean positions of the ITCZ and also produced a rainfall increase of 0.8 to $1 \mathrm{~m} \mathrm{yr}^{-1}$ across much of tropical Brazil. Their results are qualitatively equivalent to those of another coupled GCM study designed to address slowdown of thermohaline circulation (THC) during the Younger Dryas (Schiller et al., 1997). As in the study of Vellinga and Wood (2002), the largest precipitation anomalies were observed in the tropical Atlantic and the adjacent Amazon basin. In summary, observational and modelling studies demonstrate: (1) the existence of decadal-scale variability of the tropical-Atlantic meridional SST gradient, (2) the existence of much larger variability of the tropical-Atlantic meridional SST gradient at longer timescales due to past changes in Atlantic THC, and (3) the effects of this tropical Atlantic variability on the precipitation of the adjacent Amazon extending, perhaps, to the Altiplano.

The Bond events of the Holocene (Bond et al., 1997, 2001) represent the largest-amplitude climatic events of the Holocene in the Northern Hemisphere monsoon region (Neff et al., 2001; Fleitmann et al., 2003; Wang et al., 2005), where they apparently were registered as mega-droughts. Beyond the northern monsoon region the manifestation and magnitude of these events is less well known-it is interesting to note that there is little published empirical evidence of these events in high-resolution ENSO reconstructions, perhaps suggesting that their effect on tropical Pacific dynamics may not have been great. Individual Bond events may be of variable causes and perhaps were manifested differently in terms of their atmospheric and oceanic footprint. It now is increasingly clear that many (if not all) Bond events are related to solar variability (Wang et al., 2005, Kerr, 2005). However, climate forcing of the latest Bond event, the Little Ice Age, represented by a strong cooling of the North Atlantic sector (Bond et al., 1999), has been convincingly ascribed largely to volcanic forcing (Hegerl et al., 2003). Additionally, both the $8.2 \mathrm{ka}$ and Younger Dryas events occurred at a time when Northern Hemisphere continental glaciers still existed, and there is strong evidence that both of these climatic events featured partial shutdowns of Atlantic THC due to meltwater input (Barber et al., 1999; Clark et al., 2001; Rohling and Pälike, 2005). However produced, all of the Bond events must have been associated with a cooling of the North Atlantic, as they were first identified by the increased abundance of ice-rafted debris in sediment cores from this region (Bond et al., 1997). In light of the previous discussion (e.g. Vellinga and Wood, 2002), it seems reasonable to expect that every Bond event was repre-

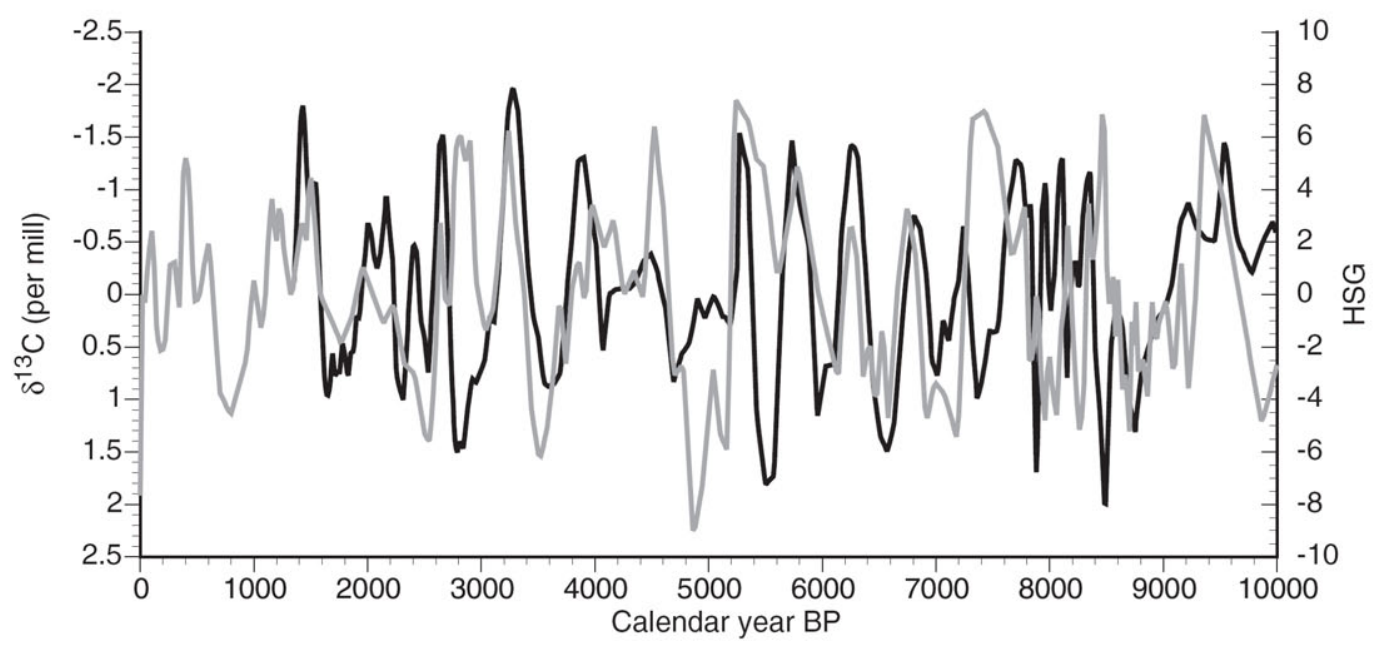

Figure 6 A comparison of the detrended $\delta^{13} \mathrm{C}$ record (black line) from NE98-PC2 (see text) with the percentage haematite stained grain (HSG) record (grey line) from VM29-191 (Bond et al., 2001). 
sented by large negative values of the north-south tropical-Atlantic meridional SST gradient, and we posit that they may have resulted in increased precipitation on the Altiplano. If so, then precipitation was oppositely phased in Bond events of the southern tropics of South America relative to those of the Northern Hemisphere monsoon region.

To evaluate the relationship between North Atlantic climate and precipitation variation on the Altiplano, we compared our detrended $\delta^{13} \mathrm{C}$ record from Lake Titicaca with the Holocene ice-rafted debris record from the North Atlantic (Bond et al., 1997). Although admittedly imperfect, the two records appear to show coherent patterns of variation through time (Fig. 6). As we hypothesized, times of anomalously wet conditions on the Altiplano (depleted $\delta^{13} \mathrm{C}$, rising or high lake level) appear to be associated with cold conditions in the North Atlantic region (high values of HSG). We believe that discrepancies between the two records can be reasonably ascribed to imprecision in our age model: offsets between the two time series are well within the $2 \sigma$ ranges of the calibrated radiocarbon dates. In addition, nonlinearity in the transmission of the climate forcing during different mean states may contribute to some of the differences between the two time series. The relationship between lake-level variation at Lake Titicaca and Holocene Bond events also is supported by the more coarsely resolved (but very well documented) record of water-level fluctuations over the past 4,000 years based on the sedimentology of cores from the shallow basin of the lake (Abbott et al., 1997). Thus, our data support the influence of North Atlantic SSTs on precipitation variation in the tropical Andes at centennial timescales and the anti-phasing between precipitation in the Northern Hemisphere monsoon sector and the South American summer monsoon.

The strong correlation of the North Atlantic drift records with cosmogenic ${ }^{14} \mathrm{C}$ and ${ }^{10} \mathrm{Be}$ records has previously been used to argue that the periodic behavior in North Atlantic climate is related to changes in solar output, with cooling during times of reduced solar output (Bond et al., 2001). Although our isotopic data from Lake Titicaca exhibit many of the periodicities evident in the ${ }^{14} \mathrm{C}$ record (Stuiver and Braziunas, 1989), we do not argue on this basis for solar forcing of precipitation variation on the Altiplano. Clearly the pacing of precipitation change is irregular (Fig. 5), not cyclic, with event spacing varying from 100 to over $600 \mathrm{yr}$. In any case, although solar variability may be involved in forcing Bond events, and by implication regional precipitation, our intent here is to argue for a possible important role for the Atlantic in forcing centennial-scale climate variation on the Altiplano, independent of the ultimate driver(s) of Atlantic variability.

What is the significance of observing Bond events in the climate signal of Lake Titicaca? So far, this is the only site located in the Southern Hemisphere where Bond events have been recognized. It appears that the largest climatic fluctuations on the Altiplano during the Holocene were related to the Bond events, although these events were superimposed upon more slowly varying (orbital) insolation-forced precipitation changes. The manifestation of Bond events, as periods of increased precipitation in the Southern Hemisphere, is anti-phased with their manifestation as periods of increased aridity in the northern tropics. If solar forcing of these important climate events is to be supported, the mechanism will have to be able to rationalize the asymmetry of precipitation response on opposite sides of the equator. Finally, it is interesting to ponder the impact on regional climate of a future realization of a Bond event (or solar minimum).

\section{Acknowledgements}

We thank G. Seltzer, J. Broda, M. Grove, H. Rowe, P. Tapia, G. Mollaricon, and N. Catari for assistance with fieldwork and acknowledge the cooperation of M. Revollo, J. Sanjines, and the Autoridade del Lago Titicaca, Bolivia/Peru, in facilitating our research. We thank Don Rodbell, David Anderson, and two anonymous reviewers for their help in improving this paper. This research was funded by US National Science Foundation (Earth Systems History) grants to SCF and PAB. Dedicated to Geoffrey Seltzer in memory of all the wonderful times we spent together on Lake Titicaca during the last ten years.

\section{References}

Abbott M, Binford MB, Brenner MW, Kelts KR. 1997. A $3500{ }^{14}$ Cyr high resolution record of lake level changes in Lake Titicaca, South America. Quaternary Research 47: 169-180.

Aceituno P. 1988. On the functioning of the Southern Oscillation in the South American sector. Monthly Weather Review 116: 505-524.

Ambrizzi T, Souza EB, Pulwarty RS. 2004. The Walker and Hadley circulations and associated ENSO impacts on South American seasonal rainfall. In The Hadley Circulation: Present, Past, and Future, Diaz HA, Bradley RS (eds). Kluwer: Dordrecht; 203-235.

Baker PA, Seltzer GO, Fritz SC, Dunbar RB, Grove MJ, Cross SL, Tapia P, Rowe HD, Broda JP. 2001a. The history of South American tropical precipitation for the past 25,000 years. Science 291: 640-643.

Baker PA, Rigsby CA, Seltzer GO, Fritz S, Lowenstein T, Bacher N, Veliz C. 2001b. Tropical climate changes at millennial and orbital timescales on the Bolivian Altiplano. Nature 409: 698-701.

Barber DC, Dyke A, Hillaire-Marcel C, Jennings AE, Andrews JT, Kerwin MW, Bilodeau G, McNeely R, Southon J, Morehead MD, Gagnon J. 1999. Forcing of the cold event of 8,200 years ago by catastrophic drainage of Laurentide lakes. Nature 400: 344-348.

Bond G, Showers W, Cheseby M, Lotti R, Almasi P, deMenocal P, Priore P, Cullen H, Hajdas I, Bonani G. 1997. A pervasive millennialscale cycle in North Atlantic Holocene and Glacial climates. Science 278: 1257-1266.

Bond GC, Showers W, Elliot M, Evans M, Lotti R, Hajdas I, Bonani G, Johnson S. 1999. The North Atlantic's 1-2 kyr climate rhythm: relation to Heinrich events, Dansgaard/Oeschger Cycles and the Little Ice Age. In Mechanisms of Global Climate Change at Millennial Time Scales, Clark PU, Webb RS, Keigwin L (eds). Geophysical Monograph 112, American Geophysical Union: Washington, DC; 35-58.

Bond G, Kromer B, Beer J, Muscheler R, Evans MN, Showers W, Hoffmann S, Lotti-Bond R, Hajdas I, Bonani G. 2001. Persistent solar influence on North Atlantic climate during the Holocene. Science 294: 2130-2136.

Bradley RS, Vuille M, Hardy D, Thompson LG. 2003. Low latitude ice cores record Pacific sea surface temperatures. Geophysical Research Letters 30: 1174. doi:10.1029/2002GL016546.

Chang P, Ji L, Li H. 1997. A decadal climate variation in the tropical Atlantic Ocean from thermodynamic air-sea interactions. Nature 385: 516-517.

Chiang JCH, Kushnir Y, Giannini A. 2002. Deconstructing Atlantic Intertropical Convergence Zone variability: influence of the local cross-equatorial sea surface temperature gradient and remote forcing from the eastern equatorial Pacific. Journal of Geophysical Research 107. doi: 10.1029/2001JD000307.

Clark PU, Marshall SJ, Clarke GKC, Hostetler SW, Licciardi JM, Teller JT. 2001. Freshwater forcing of abrupt climate change during the last glaciation Science 293: 283-287. 
Clemens S. 2005. Millennial-band climate spectrum resolved and linked to centennial-scale solar cycles. Quaternary Science Reviews 24: 521-531.

Cross SL, Baker PA, Seltzer GO, Fritz SC, Dunbar RB. 2000. A new estimate of the Holocene lowstand level of Lake Titicaca and implications for tropical paleohydrology. The Holocene 10: 21-32.

Fleitmann D, Burns SJ, Mudelsee M, Neff U, Kramers J, Mangini A, Matter A. 2003. Holocene forcing of the Indian monsoon recorded in a stalagmite from southern Oman. Science 300: 1737-1739.

Fu R, Li W. 2004. The influence of the land surface on the transition from dry to wet season in Amazonia. Theoretical and Applied Climatology 78: 97-110.

Garreaud R, Vuille M, Clement AC. 2003. The climate of the Altiplano: observed current conditions and mechanisms of past changes. Palaeogeography, Palaeoclimatology, Palaeoecology 194: 5-22.

Hastenrath S, Heller L. 1977. Dynamics of climatic hazards in northeast Brazil. Quarterly Journal of the Royal Meteorological Society 110: 77-92.

Hastenrath S, Polzin D, Francou B. 2004. Circulation variability reflected in ice core and lake records of the southern tropical Andes. Climatic Change 64: 361-375.

Hegerl G, Crowley TJ, Baum SK, Kim K-Y, Hyde WT. 2003. Detection of volcanic, solar and greenhouse gas signals in paleoreconstructions of Northern Hemispheric temperature. Geophysical Research Letters 30: 1242. doi: 10.1029/2002Gl016635.

Hodell DA, Brenner M, Curtis JH, Guilderson T. 2001. Solar forcing of drought frequency in the Maya lowlands. Science 292: 1367- 1370 .

Hu FS, Kaufman D, Yoneji S, Nelson D, Shemesh A, Huang Y, Tian J, Bond G, Clegg B, Brown T. 2003. Cyclic variation and solar forcing of Holocene climate in the Alaskan subarctic. Science 301: 1890- 1893.

Kerr R. 2005. Changes in the sun may sway the tropical monsoon. Science 308: 787.

Lenters J, Cook K. 1997. On the origin of the Bolivian high and related circulation features of the South American climate. Journal of the Atmospheric Sciences 54: 656-677.

Mann ME, Lees JM. 1996. Robust estimation of background noise and signal detection in climatic time series. Climatic Change 33: 409-445.

Marengo JA. 2004. Interdecadal variability and trends of rainfall across the Amazon basin. Theoretical and Applied Climatology 78: 79-96.

Marshall J, Kushnir Y, Battisti D, Chang P, Czaja A, Dickson R, Hurrell J, McCartney M, Saravanan R, Visbeck M. 2001. North Atlantic climate variability: phenomena, impacts and mechanisms. International Journal of Climatology 21: 1863-1898.

Melice J, Roucou P. 1998. Decadal time scale variability recorded in the Quelccaya summit ice core ${ }^{18} \mathrm{O}$ isotopic ratio series and its relation with the sea surface temperature. Climate Dynamics 14: 117-132.
Neff U, Burns SJ, Mangini A, Mudelsee M, Fleitmann D, Matter A. 2001. Strong coherence between solar variability and the monsoon in Oman between 9 and 6 kyr ago. Nature 411: 290-293.

Nobre P, Shukla J. 1996. Variations of sea surface temperature, wind stress, and rainfall over the tropical Atlantic and South America. Journal of Climate 9: 2464-2479.

Paillard D, Labeyrie L, Yiou P. 1996. Macintosh program performs timeseries analysis. EOS, Transactions, American Geophysical Union 77: 379. http://www.agu.org/eos_elec/96097e.html

Rigsby CA, Baker PA, Aldenderfer MS. 2003. Fluvial history of the Rio Ilave valley, Peru, and its relationship to climate and human history. Palaeogeography, Palaeoclimatology, Palaeoecology 194: 165-185.

Roche MA, Bourges J, Cortes J, Mattos R. 1992. Climatology and hydrology of the Lake Titicaca basin. In Lake Titicaca: A Synthesis of Limnological Knowledge, Dejoux C, Iltis A (eds). Kluwer: Dordrecht; 63-84.

Rodbell DT, Seltzer GO, Anderson DM, Abbott MB, Enfield DB, Newman JH. 1999. An 15,000-year record of El Niño-driven alluviation in southwestern Ecuador. Science 283: 516-520.

Rohling EJ, Pälike H. 2005. Centennial-scale climate cooling with a sudden cold event around 8,200 years ago. Nature 434: 975-979.

Ropelewski C, Halpert MS. 1987. Global and regional scale precipitation patterns associated with the El Niño-Southern Oscillation. Monthly Weather Review 115: 1606-1626.

Rowe HD, Dunbar RB, Mucciarone DA, Seltzer GO, Baker PA, Fritz SC. 2002. Insolation, moisture balance and climate change on the South American Altiplano since the last glacial maximum. Climatic Change 52: 175-199.

Schiller A, Mikolajewicz U, Voss R. 1997. The stability of the North Atlantic thermohaline circulation in a coupled ocean-atmosphere general circulation model. Climate Dynamics 13: 325-347.

Seltzer G, Cross S, Baker P, Dunbar R, Fritz S. 1998. High-resolution seismic reflection profiles from Lake Titicaca, Peru/Bolivia. Geology 26: 167-170.

Stuiver M, Braziunas TF. 1989. Atmospheric ${ }^{14} \mathrm{C}$ and century-scale solar oscillations. Nature 338: 405-408.

Stuiver M, Reimer PJ. 2004. CALIB 4.4. [WWW program and documentation]. Vellinga M, Wood RA. 2002. Global climatic impacts of a collapse of the Atlantic thermohaline circulation. Climatic Change 54: 251-267.

Vuille M, Bradley RS, Keimig F. 2000. Interannual climate variability in the Central Andes and its relation to tropical Pacific and Atlantic forcing. Journal of Geophysical Research 105: 12 447-12 460.

Wang Y, Cheng H, Edwards RL, He Y, Kong X, An Z, Wu J, Kelly MJ, Dykoski CA, Li X. 2005. The Holocene Asian monsoon: links to solar changes and North Atlantic climate. Science 308: 854-857.

Zhou J, Lau KM. 1998. Does a monsoon climate exist over South America? Journal of Climate 11: 1020-2040. 